\title{
Feeding strategy assessment through fatty acid profiles in muscles of adult sea lampreys from the western Iberian coast
}

\author{
MARIA JOÃO LANÇA ${ }^{1,2}$, MARIA MACHADO ${ }^{2}$, RUI FERREIRA ${ }^{2,3}$, \\ ISABEL ALVES-PEREIRA ${ }^{2,3}$, BERNARDO RUIVO QUINTELLA ${ }^{4,5}$ \\ and PEDRO RAPOSO DE ALMEIDA ${ }^{4,6}$ \\ ${ }^{1}$ School of Science and Technology, Department of Animal Science, University of Évora, Largo dos Colegiais 2, \\ 7004-516 Evora, Portugal. E-mail: mjlanca@uevora.pt \\ ${ }^{2}$ Institute of Mediterranean Agricultural and Environmental Sciences (ICAAM), University of Évora, Núcleo da Mitra, \\ Apartado 94, 7002-554, Évora, Portugal. \\ ${ }^{3}$ School of Science and Technology, Department of Chemistry, University of Évora, Largo dos Colegiais 2, \\ 7004-516 Évora, Portugal. \\ ${ }^{4}$ Center of Oceanography, Faculty of Sciences of the University of Lisbon, Campo Grande, 1749-016 Lisbon, Portugal. \\ ${ }^{5}$ Department of Animal Biology, Faculty of Sciences of the University of Lisbon, Campo Grande, \\ 1749-016 Lisbon, Portugal. \\ ${ }^{6}$ School of Science and Technology, Department of Biology, University of Évora, Largo dos Colegiais 2, \\ 7004-516 Évora, Portugal.
}

SUMMARY: The fatty acid signature of sea lamprey Petromyzon marinus (L.) muscle was used as a tool to detect feeding strategies used during the parasitic marine trophic phase of the species. Adult sea lampreys were collected near the mouth of six Portuguese rivers (Minho, Lima, Douro, Vouga, Mondego and Tagus) and muscle fatty acid profile was characterized. The analysis of fatty acid composition of muscle neutral lipids showed the formation of two groups, indicating that two feeding strategies may have been used by sea lampreys during the parasitic phase, based on the availability of $\omega-3$ and $\omega-6$ $P U F A$ and on evidence of phytoplankton/zooplankton and bacterial detritus contribution in the sea lamprey host preferences. Two distinct lipid profiles were observed, probably related to two different trophic approaches, one typical of a top predator of a marine food web with a planktonic support, and the other much more diverse, including the same planktonic markers, together with biochemical clues that probably resulted from a parasitic phase that directly targeted fish that consumed detritus and benthic algae and/or fish from a food web with a detritivorous base.

Keywords: Petromyzon marinus, feeding strategies, marine phase, fatty acids, Portugal.

RESUMEN: EVALUACIÓN DE ESTRATEGIAS DE ALIMENTACIÓN MEDIANTE LA UTILIZACIÓN DE PERFILES DE ÁCIDOS GRASOS EN LOS MÚSCULOS DE LAMPREA MARINA ADULTA DE LA COSTA OCCIDENTAL IBÉRICA. - Las composiciones de los ácidos grasos en los músculos de lamprea marina Petromyzon marinus (L.) fueron usadas como herramienta para detectar la estrategia de alimentación de la especie durante la fase marina de alimentación parasítica. Se recolectaron individuos adultos cerca de la desembocadura de las cuencas hidrográficas de seis ríos portugueses (Miño, Lima, Duero, Vouga, Mondego y Tajo) y se caracterizaron los perfiles de los contenidos en ácidos grasos en el músculo. El análisis de la composición en ácidos grasos de los lípidos neutros del músculo muestra la formación de dos grupos, lo que indica que las lampreas en su fase parasítica pueden usar dos estrategias de alimentación basadas en la disponibilidad de $\omega-3$ y $\omega-6$ PUFA y en la contribución de fitoplancton/zooplancton y detritos bacterianos en las preferencias alimenticias de los huéspedes de la lamprea marina. Se observaron dos perfiles lipídicos distintos que, probablemente, están relacionados con dos aproximaciones tróficas diferentes, una típica de un predador superior de cadena trófica marina con una base planctónica y otra, mucho más variada, que incluye los mismos marcadores planctónicos junto a indicios bioquímicos que probablemente son el resultado de una fase parasítica de peces consumidores de detritus y algas bentónicas, y/o la depredación de peces de cadena trófica con una base detritívora.

Palabras clave: Petromyzon marinus, estrategias de alimentación, fase marina, ácidos grasos, Portugal. 


\section{INTRODUCTION}

The life cycle of the sea lamprey Petromyzon marinus (L.) contains a microphagic larval phase, which is spent in freshwater (Potter 1980). After four to seven years, a metamorphosis period occurs which transforms the microphagic filter-feeding larvae into pelagic juveniles. This is a non-trophic period during which lamprey utilize the lipid reserves accumulated in the larval phase (Bird and Potter 1983). The pelagic juveniles then migrate downstream to the sea, where they begin the parasitic stage of their life cycle, feeding primarily on blood and muscle tissue of marine fish for as much as 13 to 28 months (Beamish 1980, Silva et al. 2013a). This marine phase is accompanied by the deposition of large amounts of lipids, particularly in the musculature, which act as the primary energy source during the upstream migration (Sheridan 1988, Bird et al. 1993). At the end of this oceanic phase the adults cease feeding and enter rivers to migrate upstream, where they spawn and die (Larsen 1980).

Little information on the feeding ecology of sea lampreys in the marine environment is available because few specimens have been captured in the ocean and reports of fish with attachment scars are relatively scarce (Farmer 1980). Nonetheless, sea lamprey seem to prefer fish that have smaller, less protective scales and are thus easier to feed on and fish with benthopelagic or pelagic modes of life. Marine organisms reported to have been preyed on by sea lamprey include bony fish, elasmobranchs and cetaceans (Beamish 1980, Halliday 1991, Nichols and Hamilton 2004). This paucity of information concerning the ecology of adult sea lamprey during the parasitic marine stage, including the preferential host species, is shared by most of the remaining species of anadromous parasitic lampreys (Renaud et al. 2009).

It has been reported that fatty acids can be used as biological markers and general diet indicators in marine ecosystems (Sargent et al. 1987). An important aspect of fatty acid trophic markers is that fatty acid composition of an animal represents the timeintegrated dietary intake and, because lipid metabolism and storage in animals are organ-specific, fatty acid markers should be extracted from individual tissues or body parts (Napolitano 1999). The fatty acid profile of adipose tissue triacylglycerols is particularly useful as a trophic marker because fatty acids accumulate over time, representing an integration of dietary intake over days, weeks or even months (Hendersen and Sargent 1981, Leger et al. 1981, Iverson 2009), whereas examinations of gut content of an animal provide only information of the last ingesta (Napolitano 1999).

More recently, fatty acids have been used to purposely identify food web relationships because of their biological specificity and because, although organisms are able to biosynthesize and modify fatty acids chains, these processes are phylogenetically limited (Iverson
2009). Previous studies have used fatty acids as biomarkers for bacteria (Rajendran et al. 1993), diatoms (Parrish et al. 2000), zooplankton and crustacean zooplankton (Falk-Petersen et al. 2002, Brett et al. 2009), macroalgae (Johns et al. 1979, Khotimchenko and Vaskovsky 1990) and vascular plants (Wannigama et al. 1981).

In a previous study, the authors found that the fatty acid profile of the neutral and polar lipids of sea lamprey muscle at the beginning of upriver migration show differences consistent with the river basin of origin (Pinela et al. 2009), thus raising some questions concerning the meaning of this discovery. A subsequent study concluded that muscle fatty acid profiles of neutral lipids could be used as a signature of sea lamprey diets during their marine trophic phase (Lança et al. 2011). Bearing this in mind, the main objective of this study was to assess the feeding strategy of sea lamprey during the marine trophic phase off the Portuguese coast by analysing the fatty acid composition of muscle neutral lipids.

Some of the sea lampreys that enter Portuguese rivers during their spawning migration attain $2.0 \mathrm{~kg}$ (unpublished data), which means that they must have been targeting large preys. Besides the scientific interest of revealing part of the feeding ecology of this species, there is also some concern regarding the management and conservation of this important resource for inland Portuguese fisheries. In fact, it is important to know as much as possible about the ecology of their adult trophic phase, in particular with regard to the range of dispersion in the marine environment. This knowledge may provide the bases for the spatial definition of future conservation units, which may range from a single basin level to a more regional, or even international, geographical scale. As a result of our constant demand for new fishing grounds, particularly in the deep ocean, measures of this type will be necessary in the near future in order to avoid the collapse of this fishery due to a potential overexploitation of their preferential hosts by commercial fisheries.

\section{MATERIALS AND METHODS}

\section{Samples and sampling sites}

Sampling occurred at the peak of the sea lamprey spawning migration period (March 2008) in the basins of six Portuguese rivers (Minho, Lima, Douro, Vouga, Mondego and Tagus). The Minho, Lima and Douro river basins are located in the northwest area of Portugal, whereas the Vouga, Mondego and Tagus river basins are located in the central region of the country. Sea lampreys were collected with trammel nets by professional fishermen near the mouth of each river, except in the River Tagus, where individuals were caught $67 \mathrm{~km}$ upstream from the river mouth (Fig. 1). A total of 115 sea lampreys ( $c a .19$ individuals per river basin) were sampled and transported alive to the laboratory 


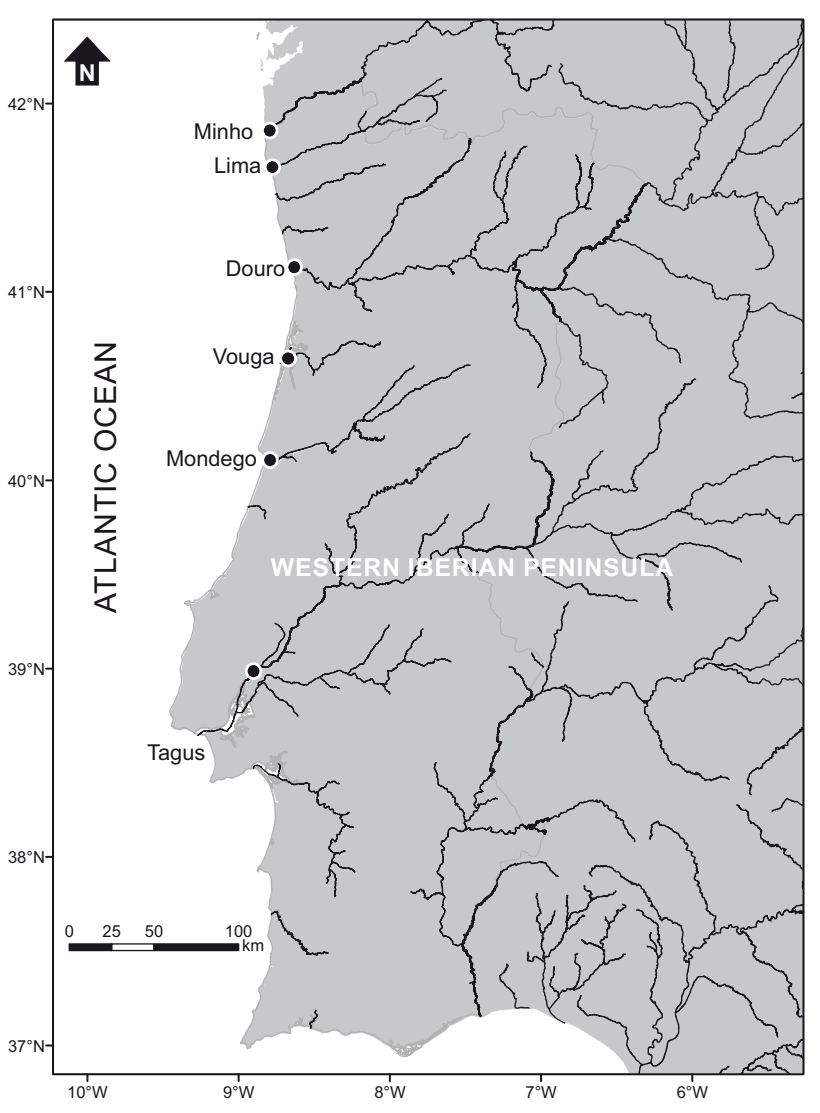

FIG. 1. - Location of the sampling sites of sea lamprey captures (Petromyzon marinus, L.) (O) in the Rivers Minho, Lima, Douro, Vouga, Mondego and Tagus (Portugal).

in a $0.4-\mathrm{m}^{3}$ capacity tank equipped with an appropriate life-support system including aeration, water quality maintenance system and temperature control. Transportation time between the sampling site and the laboratory where the individuals were processed ranged from 3 to 5 hours.

\section{Tissue preparation and collection}

Data on body total mass $\left(M_{\mathrm{T}}\right.$, nearest $\left.\mathrm{g}\right)$ and total length $\left(L_{\mathrm{T}}\right.$, nearest $\mathrm{mm}$ - length between the beginning of the oral disk to the end of the caudal fin) was registered for each sea lamprey. All trunk muscle between the posterior edge of the last branchial opening and the anterior edge of the cloacal slit on the left flank of the animal were collected, washed with physiological saline solution and immediately stored in liquid nitrogen $\left(-196^{\circ} \mathrm{C}\right)$ until processing in the laboratory.

\section{Muscle lipid extraction and fatty acid analysis}

Muscle lipids were obtained using accelerated solvent extraction, an automated procedure that makes use of pressurized solvents at high temperatures. To prepare for extraction, the tissue samples were removed from liquid nitrogen, weighed and lyophilized until constant mass to determine the percentage of water loss
$\left(W_{\mathrm{M}}\right)$. Aliquots of a 1-g portion of lyophilized muscle samples were weighed on an analytical balance (Mettler AT201; Greifensee, Switzerland) and their masses were recorded to the nearest $0.01 \mathrm{mg}$. Aliquots were then pulverized in an aluminum mortar with a stainless steel pestle, both cooled in liquid nitrogen. The tissue powder was combined with $1 \mathrm{~g}$ of hydromatrix drying agent (Diatomaceous Earth, hydromatrix Varian, P/N 049458), the hydromatrix mixture (tissue powder plus hydromatrix drying agent) was transferred to an 11-mL stainless steel extraction cell fitted with two cellulose filters, and additional hydromatrix drying agent was added to fill the cell. Nonadecanoic acid (C19:0) was added as a surrogate to assess the performance of all subsequent sample preparation steps because the tissues under study were known to lack the corresponding fatty acid. The total lipid sample was then extracted with a mixture of $60 \%$ chloroform and $40 \%$ methanol (Merck; Darmstadt, Germany) at $100^{\circ} \mathrm{C}$ and $13.8 \mathrm{MPa}$. Both extraction solvents were residue-analysis grade and were treated with $100 \mathrm{mg} \mathrm{L}^{-1}$ BHT (3,5-Di-tertbutyl-4-hydroxytoluene, Merck; Darmstadt, Germany) as an antioxidant. Two static extraction cycles were carried out during a five-minute period each. The crude extract was then concentrated under a stream of nitrogen and vacuum using a TurboVap apparatus (Zymark; Hopkinton, MA) set at a bath temperature of $50^{\circ} \mathrm{C}$ and the dry mass of recovered material was measured to the nearest $0.01 \mathrm{mg}$ to determine muscle total lipids $\left(T L_{\mathrm{M}}\right)$. Then, each sample was reconstituted in 20-30 volumes of ice-cold acetone to separate neutral lipids $(N L)$ from polar lipids $(P L)$. The samples were mixed by vortexing for one minute and left on ice for 60 minutes, and then the $N L$ plus $P L$ fraction was centrifuged at $3000 \mathrm{~g}$ for 30 minutes. The upper phase, corresponding to $N L$, was removed as completely as possible, evaporated under nitrogen and vacuum and measured to the nearest $0.01 \mathrm{mg}$ to determine muscle neutral lipids $\left(N L_{\mathrm{M}}\right)$. The $N L$ phase was saponified in methanolic $\mathrm{NaOH} 0.5 \mathrm{~N}$ at $70^{\circ} \mathrm{C}$ for $15 \mathrm{~min}$. For transesterification, samples were treated with $1 \mathrm{~mL}$ of newly opened $\mathrm{BF}_{3}$ in methanol (10 $\mathrm{g} \mathrm{BF}_{3} / \mathrm{CH}_{3} \mathrm{OH}$, Merk-Schuchardt, Germany) in order to give fatty acid methyl esters (FAME) according to the procedure of Morrison and Smith (1964).

The FAME were analysed by liquid-gas chromatography in a Hewlett Packard HP 6890 Series GC System equipped with a split-splitless injector, an autosampler, a flame-ionization detector (FID), an Omegawax 320 fused silica capillary column $(30 \mathrm{~m} \times 0.32$ $\mathrm{mm}$ i.d., $0.25 \mu \mathrm{m}$ film thickness, Supelco, Bellafonte, PA) and HPChem software (2002). The chromatographic conditions were as follows: oven temperature ranged from $140^{\circ}$ to $240^{\circ} \mathrm{C}$ with a ramping rate of $4^{\circ} \mathrm{C}$ $\mathrm{min}^{-1}$; injection port temperature was $250^{\circ} \mathrm{C}$ and FID was $270^{\circ} \mathrm{C}$. The carrier gas was $(\mathrm{He})$ and flow rate was $1.2 \mathrm{~mL} \mathrm{~min}^{-1}$. The resulting peak areas were corrected by theoretical relative FID response factors (Ackman 2002). The FAME were identified by comparison of their retention times with known standards (37-com- 
TABLE 1. - Mean ( \pm standard deviation) total length $\left(L_{\mathrm{T}}\right)$, total mass $\left(M_{\mathrm{T}}\right)$, muscle total lipids $\left(T L_{\mathrm{M}}\right)$, muscle neutral lipids $\left(N L_{\mathrm{M}}\right)$ and muscle water content $\left(W_{\mathrm{M}}\right)$ of sea lampreys (Petromyzon marinus) from Cluster Groups I and II.

\begin{tabular}{lcccrr}
\hline & $L_{\mathrm{T}}, \mathrm{mm}$ & $M_{\mathrm{T}}, \mathrm{g}$ & $\mathrm{TL}_{M}, \mathrm{mg} \mathrm{g}^{-1}$ & $N L_{\mathrm{M}}, \mathrm{mg} \mathrm{g}^{-1}$ & $W_{\mathrm{M}}, \%$ \\
\hline Group I (N=59) & $864.9 \pm 61.0$ & $1222.9 \pm 194.0$ & $327.4 \pm 90.0$ & $243.5 \pm 50.9$ & $67.1 \pm 4.7$ \\
Group II (N=51) & $868.6 \pm 48.9$ & $1210 \pm 193.9$ & $404.5 \pm 126.9$ & $251.6 \pm 43.2$ & $67 \pm 3.0$ \\
\hline
\end{tabular}

$\mathrm{NL}$, neutral lipid content expressed as $\mathrm{mg} \mathrm{g}^{-1}$ dry tissue; TL, total lipid content expressed in $\mathrm{mg}$ of $\mathrm{TL} \mathrm{g}^{-1}$ dry tissue.

ponent FAME mix, Supelco plus C22:5 03 fatty acid methyl ester) chromatographed in identical gas chromatography conditions. For each sample, the relative fatty acid composition was quantified and data are presented as the weight percentage for fatty acid composition. Fatty acids were designated according to the nomenclature of the International Union of Pure and Applied Chemistry (IUPAC) for carbon chain length: number of double bonds and position of the double bond closest to the omega carbon.

The frequency of occurrence of a certain fatty acid was calculated as the percentage of sea lampreys from a specific group (geographical or other) that had that fatty acid in their muscle samples.

\section{Data analysis and interpretation}

The SPSS statistical package for Windows (version 18.0) and Primer 6.0 were used for data processing and statistical analysis. Data were arcsine transformed to meet assumptions of normality, independence and homoscedasticity. The integrated chromatogram values for each fatty acid were expressed as a percentage of the total sum of fatty acids identified in order to eliminate concentration effects.
Multivariate analysis of variance (MANOVA) was used to see the main and interaction effect of the categorical variable (gender) on $M_{\mathrm{T}}, L_{\mathrm{T}}$, muscle total lipids $\left(T L_{\mathrm{M}}\right)$, muscle neutral lipids $\left(N L_{\mathrm{M}}\right)$ and muscle water content $\left(W_{\mathrm{M}}\right)$. The Spearman rank correlation was used to analyse the relationship between muscle total lipids and muscle water content.

The cluster analysis is a numerical technique for defining groups of related samples based on high similarity coefficients computed between each pair of samples, which are then clustered. In most clustering procedures the nucleus of clusters (centroid) is formed by joining the samples with the greatest similarity and gradually admitting more samples as the similarity coefficient is lowered (Kaiser and Esterby 1991). A group average cluster analysis was performed using Spearman rank correlation to investigate the existence of groups of samples with similar muscle $N L$ fatty acid profiles.

A distance-based permutational multivariate analysis of variance (PERMANOVA) based on the previously obtained Spearman rank correlation resemblance matrix was used to compare fatty acid muscle $N L$ profile among the groups that corresponded to clusters obtained by the cluster analysis. The analysis was

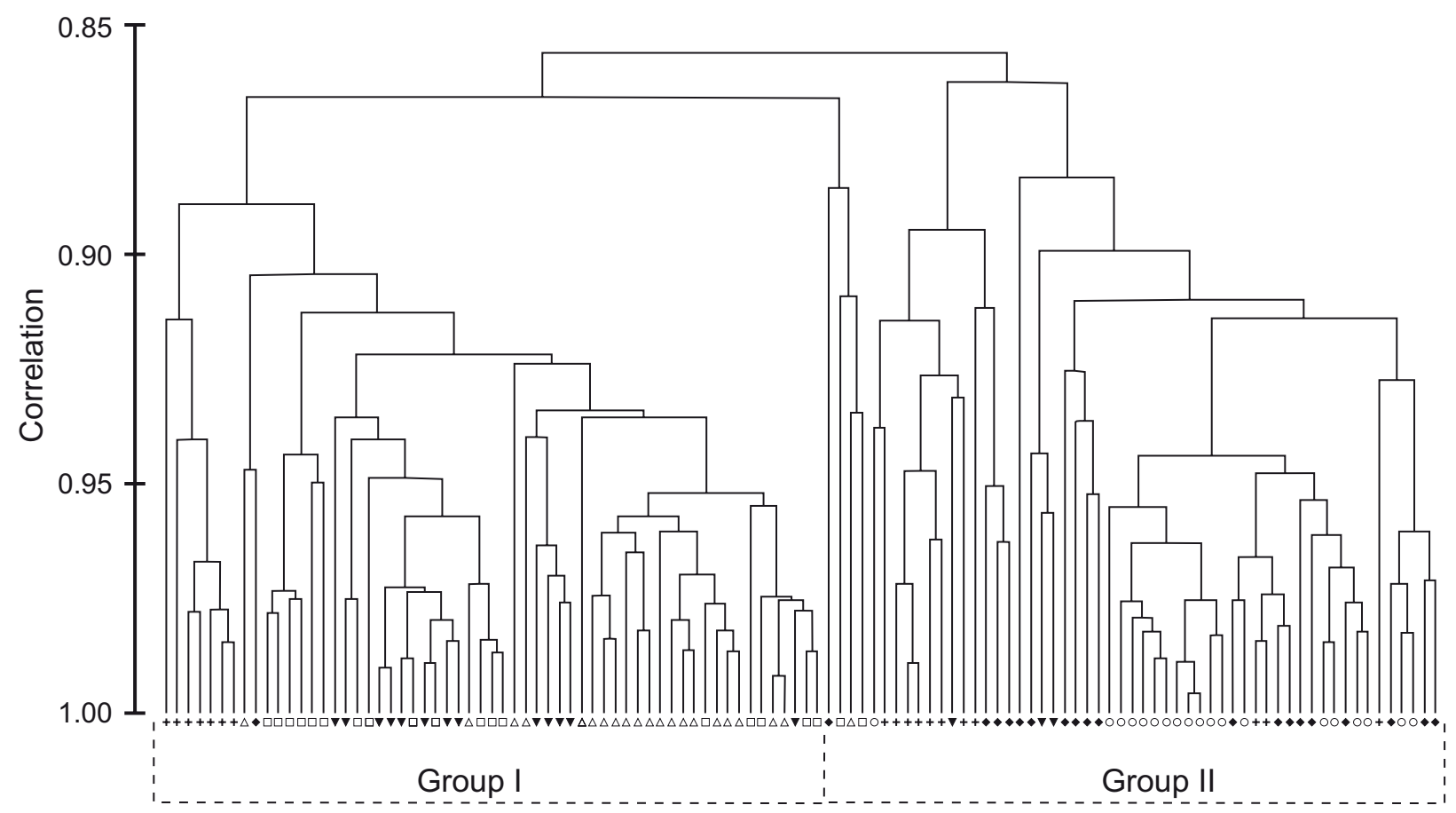

FIG. 2. - Cluster of the fatty acid profiles of sea lampreys (Petromyzon marinus) from the six Portuguese basins. ( $)$ ) Minho; (+) Lima; (O) Douro; $(\triangle)$ Vouga; $(\diamond)$ Mondego; $(\square)$ Tagus. 
done using 999 random permutations of the appropriate units (Anderson and ter Braak 2003). The data set comprised 110 observations $\times 31$ variables (i.e. fatty acids) and the design included one factor: group (two levels fixed). A permutation test was used to assess the significance of the overall fatty acids among groups. Since the factor group was seen to be significant, it was further analysed through a pairwise comparison test. A SIMPER test (similar percentages) was used to determine the specific variables that contributed to overall differences, i.e. which fatty acids had more influence on dissimilarities among groups (Warwick et al. 1990, Clarke 1993).

\section{RESULTS}

Multivariate tests for individual effect overall revealed that gender (GLM test, $\mathrm{F}=2.156 ; \mathrm{df}=5 ; P=0.121$ ) had no significant effect on total length $\left(L_{\mathrm{T}}\right)$ and total mass $\left(M_{\mathrm{T}}\right)$. For biochemical parameters $W_{\mathrm{M}}, T L_{\mathrm{M}}$ and
$N L_{\mathrm{M}}$, the multivariate test for individual effect overall also revealed that gender (GLM test, $F=0.798$; $\mathrm{df}=5$; $P=0.498$ ) had no significant effect on these parameters. (Table 1). The correlation between muscle total lipids and water content was highly significant $((\mathrm{R}=-0.280$, $\mathrm{p}<0.01, \mathrm{~N}=107$ ).

In order to investigate the existence of groups of samples with a similar $N L$ fatty acid profile, a cluster analysis was done and revealed the existence of two groups. Group I comprised 59 individuals, most of them captured in the Minho $(81.3 \%$ of the total sea lampreys captured in this river basin), the Vouga $(100 \%)$ and the Tagus $(100 \%)$, seven individuals from the Lima (38.9\%) and one from the Mondego (5.3\%) (Fig. 2). Group II comprised 51 individuals distributed as follows: 19 from the Douro, 18 from the Mondego, 11 from the Lima and 3 from the Minho, corresponding to $100 \%, 94.7 \%, 61.1 \%$ and $18.8 \%$ of the total of sea lampreys captured in each river basin, respectively (Fig. 2).

TABLE 2. - Relative amounts as a percentage of the sum (mean \pm sd) and frequency of occurrence (FO) of fatty acids in muscle neutral lipids of sea lamprey (Petromyzon marinus) from Cluster Groups I and II.

\begin{tabular}{|c|c|c|c|c|c|}
\hline & Fatty Acids & Relative Amount Group I & FO (Group I) & Relative Amount Group II & FO (Group II) \\
\hline \multirow{12}{*}{$S F A$} & C10:0 & $0.04 \pm 0.01$ & 98.0 & $0.05 \pm 0.02$ & 100.0 \\
\hline & C12:0 & $2.17 \pm 0.54$ & 100.0 & $2.21 \pm 0.47$ & 100.0 \\
\hline & C13:0 & $0.77 \pm 0.44$ & 100.0 & $0.96 \pm 0.48$ & 100.0 \\
\hline & C14:0 & $16.96 \pm 1.65$ & 100.0 & $16.81 \pm 1.37$ & 100.0 \\
\hline & $\mathrm{C} 15: 0$ & $0.04 \pm 0.01$ & 100.0 & $0.05 \pm 0.04$ & 88.2 \\
\hline & C16:0 & $16.49 \pm 1.68$ & 100.0 & $16.28 \pm 1.78$ & 100.0 \\
\hline & $\mathrm{C} 17: 0$ & $0.02 \pm 0.01$ & 98.3 & $0.05 \pm 0.02$ & 62.8 \\
\hline & C18:0 & $2.20 \pm 0.37$ & 100.0 & $2.30 \pm 0.31$ & 100.0 \\
\hline & C20:0 & $0.16 \pm 0.08$ & 98.3 & $0.16 \pm 0.05$ & 100.0 \\
\hline & C22:0 & $0.05 \pm 0.03$ & 96.6 & $0.11 \pm 0.07$ & 98.0 \\
\hline & C23:0 & $0.03 \pm 0.02$ & 18.6 & $0.13 \pm 0.12$ & 60.8 \\
\hline & $\mathrm{C} 24: 0$ & $0.04 \pm 0.03$ & 28.8 & $0.10 \pm 0.07$ & 80.4 \\
\hline$\Sigma S F A$ & & 38.9 & & 39.2 & \\
\hline \multirow[t]{8}{*}{$M U F A$} & C14:1 & $0.93 \pm 0.28$ & 100.0 & $0.94 \pm 0.26$ & 100.0 \\
\hline & $\mathrm{C} 15: 1$ & $0.02 \pm 0.01$ & 50.9 & $0.04 \pm 0.02$ & 9.8 \\
\hline & $\mathrm{C} 16: 1$ & $38.36 \pm 1.81$ & 100.0 & $37.80 \pm 1.42$ & 100.0 \\
\hline & $\mathrm{C} 17: 1$ & $0.10 \pm 0.03$ & 100.0 & $0.11 \pm 0.06$ & 94.2 \\
\hline & 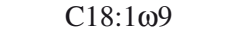 & $16.78 \pm 1.59$ & 100.0 & $17.34 \pm 1.31$ & 100.0 \\
\hline & $\mathrm{C} 20: 1 \omega 9$ & $0.30 \pm 0.13$ & 98.3 & $0.32 \pm 0.14$ & 100.0 \\
\hline & $\mathrm{C} 22: 1 \omega 9$ & $0.06 \pm 0.05$ & 100.0 & $0.10 \pm 0.06$ & 86.3 \\
\hline & $\mathrm{C} 24: 1 \omega 9$ & $0.07 \pm 0.03$ & 18.6 & $0.23 \pm 0.15$ & 100.0 \\
\hline$\Sigma M U F A$ & & 56.6 & & 56.8 & \\
\hline \multirow[t]{11}{*}{$P U F A$} & $\mathrm{C} 18: 2 \omega 6$ & $0.15 \pm 0.09$ & 100.0 & $0.28 \pm 0.17$ & 100.0 \\
\hline & $\mathrm{C} 18: 3 \omega 6$ & $0.02 \pm 0.03$ & 57.6 & $0.06 \pm 0.05$ & 72.9 \\
\hline & $\mathrm{C} 18: 3 \omega 3$ & $0.04 \pm 0.02$ & 96.6 & $0.08 \pm 0.05$ & 96.7 \\
\hline & $\mathrm{C} 20: 2 \omega 6$ & $0.11 \pm 0.09$ & 100.0 & $0.20 \pm 0.14$ & 39.2 \\
\hline & $\mathrm{C} 20: 3 \omega 6$ & $0.06 \pm 0.06$ & 100.0 & $0.08 \pm 0.05$ & 100.0 \\
\hline & $\mathrm{C} 20: 3 \omega 3$ & $0.56 \pm 0.59$ & 100.0 & $0.52 \pm 0.17$ & 100.0 \\
\hline & 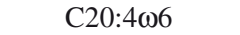 & $0.07 \pm 0.09$ & 83.1 & $0.14 \pm 0.12$ & 92.2 \\
\hline & $\mathrm{C} 20: 5 \omega 3(E P A)$ & $0.70 \pm 0.28$ & 100.0 & $0.86 \pm 0.26$ & 100.0 \\
\hline & $\mathrm{C} 22: 2 \omega 6$ & $0.05 \pm 0.04$ & 84.8 & $0.10 \pm 0.07$ & 49.0 \\
\hline & $\mathrm{C} 22: 5 \omega 3(D P A)$ & $0.70 \pm 0.27$ & 100.0 & $0.85 \pm 0.28$ & 100.0 \\
\hline & $\mathrm{C} 22: 6 \omega 3(D H A)$ & $1.20 \pm 0.58$ & 100.0 & $1.33 \pm 0.53$ & 100.0 \\
\hline \multirow[t]{7}{*}{$\Sigma P U F A$} & & 3.7 & & 4.3 & \\
\hline & $\Sigma(P U F A+M U F A)$ & 60.30 & & 61.10 & \\
\hline & $\Sigma P U F A / \Sigma S F A$ & 0.09 & & 0.11 & \\
\hline & $\Sigma \omega 3$ & 3.20 & & 3.59 & \\
\hline & $\Sigma \omega 6$ & 0.45 & & 0.65 & \\
\hline & $\Sigma \omega 3 / \Sigma \omega 6$ & 8.70 & & 6.40 & \\
\hline & $\mathrm{C} 22: 6 \omega 3 / \mathrm{C} 20: 5 \omega 3$ & 1.71 & & 1.56 & \\
\hline
\end{tabular}

SFA, saturated fatty acids; $M U F A$, monounsaturated fatty acids; $P U F A$, polyunsaturated fatty acids. 
TABLE 3. - Results of pairwise analysis testing fatty acid muscle neutral lipid profile of Petromyzon marinus between Cluster Groups I and II.

\begin{tabular}{lccc}
\hline Pairwise Groups & $\mathrm{t}$ & $\mathrm{P}($ perm $)$ & Perm \\
\hline I, II & 8.3793 & 0.001 & 998 \\
\hline
\end{tabular}

t, t-statistic; P(perm), P-value (permutations); Perm, number of permutations.

TABLE 4. - Summary of the results from the SIMPER analysis for fatty acids of muscle neutral lipids of Petromyzon marinus between individuals of Cluster Groups I and II (Average dissimilarity between groups $=8.21$ ).

\begin{tabular}{|c|c|}
\hline Parameters & Contribution to dissimilarity $(\%)$ \\
\hline $\mathrm{C} 24: 1 \omega 9$ & 7.81 \\
\hline C13:0 & 5.78 \\
\hline 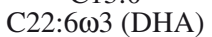 & 5.07 \\
\hline $\mathrm{C} 20: 2 \omega 6$ & 5.03 \\
\hline C16:0 & 4.60 \\
\hline $\mathrm{C} 14: 0$ & 4.27 \\
\hline $\mathrm{C} 18: 1 \omega 9$ & 4.18 \\
\hline $\mathrm{C} 24: 0$ & 3.96 \\
\hline $\mathrm{C} 20: 4 \omega 6$ & 3.76 \\
\hline C12:0 & 3.76 \\
\hline $\mathrm{C} 20: 3 \omega 3$ & 3.94 \\
\hline $\mathrm{C} 23: 0$ & 3.68 \\
\hline C16:1 & 3.65 \\
\hline $\mathrm{C} 20: 5 \omega 3$ (EPA) & 3.62 \\
\hline $\mathrm{C} 22: 5 \omega 3$ (DPA) & 3.41 \\
\hline $\mathrm{C} 14: 1$ & 3.05 \\
\hline $\mathrm{C} 22: 2 \omega 6$ & 3.05 \\
\hline $\mathrm{C} 18: 2 \omega 6$ & 3.04 \\
\hline $\mathrm{C} 20: 3 \omega 3$ & 2.95 \\
\hline $\mathrm{C} 18: 3 \omega 6$ & 2.92 \\
\hline $\mathrm{C} 20: 1 \omega 9$ & 2.52 \\
\hline $\mathrm{C} 22: 0$ & 2.38 \\
\hline C18:0 & 2.32 \\
\hline $\mathrm{C} 18: 3 \omega 3$ & 2.16 \\
\hline C17:0 & 2.02 \\
\hline
\end{tabular}

Thirty-one fatty acids were identified and compared between Group I and II. The relative amounts of fatty acid composition of neutral lipid of sea lampreys are presented in Table 2. The neutral lipid profile revealed that monounsaturated fatty acids (MUFA) are the most representative (Group I, 56.6\%; Group II, 56.8\%), followed by saturated fatty acids $(S F A)$ (Group I, 38.9; Group II, 39.2\%). Polyunsaturated fatty acids (PUFA) showed much lower relative amounts (Group I, 3.7\%; Group II, 4.3\%). The most representative SFA were C14:0 and C16:0 and the most representative $M U F A$ were $\mathrm{C} 16: 1$ and $\mathrm{C} 18: 1 \omega 9$. The most representative PUFA were $\omega 3$ fatty acids,

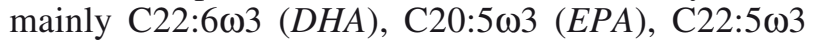
$(D P A)$ and $\mathrm{C} 20: 3 \omega 3$. Furthermore, our results demonstrated that the proportion of $D H A+E P A+D P A$ was $70.4 \%$ and $70.8 \%$ of the total muscle PUFA for Groups I and II, respectively. The percentage content of EPA and DHA demonstrates the dominance of DHA over EPA (DHA/EPA ratio). The $\omega 3 / \omega 6$ ratio for Groups I and II were 8.7 and 6.4, respectively. The abundance of fatty acids from the $\omega 3$ and $\omega 6$ series and the abundance of odd-chain fatty acids are also presented in Table 2. The PERMANOVA results showed that group factor exhibited significant differences $(P \leq 0.001)$ in the $N L_{\mathrm{M}}$ fatty acid profile of sea lamprey (Table 3). SIMPER identified several fatty acids that contribute to overall differences (Table 4). The average similarity within group individuals was 92.87 and 93.12 for Group I and Group II, respectively, whereas between Group I and II the average dissimilarity was 8.21. SIMPER analysis revealed that 25 of 31 fatty acids that were analysed contributed to the dissimilarity between Groups I and II. The fatty acid with the highest percentage of contribution to dissimilarity was $\mathrm{C} 24: 1 \omega 9(7.81 \%)$, as opposed to the situation observed for C17:0 (2.02\%) (Table 4).

\section{DISCUSSION}

The sea lamprey has important economic value in Portugal, Spain and France, where it is subjected to commercial exploitation. It is classified as 'vulnerable' in both Portugal and Spain (Cabral et al. 2005, Doadrio 2001), 'near threatened' in France (IUCN France et al. 2010), and 'least concern' according to the International Union for Conservation of Nature (IUCN) Red List of Threatened Species (Freyhof and Kottelat 2008) and the European Red List of Freshwater Fishes (Freyhof and Brooks 2011). It is curious, however, to note that this species is considered threatened in the European countries holding the main populations, namely France, Spain and Portugal (Mateus et al. 2012). The sea lamprey is also listed in the OSPAR convention list (Convention for the Protection of the Marine Environment of the North-East Atlantic) of threatened and/or declining species, in Annex III (protected fauna species) of the Bern Convention (Convention on the Conservation of European Wildlife and Natural Habitats) and in Annex II of the European Union Habitats Directive (92/43/EEC), which lists animal and plant species of interest to the European Community whose conservation requires the designation of Special Areas of Conservation (SACs) by the member states (Mateus et al. 2012).

The continental phase of the lamprey's life cycle is well known but very little information has been gathered during the oceanic phase. The available data is limited to the report of occasional captures of a few host species with lamprey scars, or occasionally still attached to the fish (Farmer 1980). Accidental captures are obviously more common in the oceanic shallower areas, were the bulk of commercial fisheries are performed, but this should not be taken as an indication of a preference for preys that live in the water column; it is probably a biased information because this type of sampling does not cover the entire bathymetric range of the potential feeding grounds. The anadromous sea lamprey is reported to attack a wide variety of marine organisms, as listed in Table 5 . The only study concerning the sea lamprey distribution during the oceanic phase of the life cycle was done by Halliday (1991), with a limited record of 80 sea lampreys captured in the northwest Atlantic. This study indicated that almost 
TABLE 5. - List of confirmed marine organisms parasitized by sea lamprey (Petromyzon marinus, L.).

\begin{tabular}{|c|c|c|}
\hline Host taxon & Ecology & Reference \\
\hline \multicolumn{3}{|l|}{ CHONDRICHTHYES } \\
\hline Basking sharks (Cetorhinus maximus Gunnerus, 1765) & Pelagic-oceanic; oceanodromous & Beamish (1980) \\
\hline Sandbar shark (Carcharhinus plumbeus Nardo, 1827) & demersal; oceanodromous & Jensen and Schwartz (1994) \\
\hline Dusky sharks (Carcharhinus obscurus Lesueur, 1818) & demersal; oceanodromous & Jensen and Schwartz (1994) \\
\hline Tiger sharks (Galeocerdo cuvier Péron and Lesueur, 1822) & demersal; oceanodromous & Jensen et al. (1998) \\
\hline Greenland shark (Somniosus microcephalus Bloch and Schneider, 1801) & demersal & Gallant et al. (2006) \\
\hline \multicolumn{3}{|l|}{ OSTEICHTHYES } \\
\hline Twaite shad (Alosa fallax Lacepède, 1803) & pelagic-neritic; anadromous & Silva et al. (2013b) \\
\hline American shad (Alosa sapidissima Wilson, 1811) & pelagic-neritic; anadromous & Beamish (1980) \\
\hline Alewife (Alosa pseudoharengus Wilson, 1811) & pelagic-neritic; anadromous & Beamish (1980) \\
\hline Blueback shad (Alosa aestivalis Mitchill, 1814) & pelagic-neritic; anadromous & Beamish (1980) \\
\hline Atlantic menhaden (Brevoortia tyrannus Latrobe, 1802) & pelagic-neritic; oceanodromous & Mansuetti (1962) \\
\hline Golden grey mullet (Liza aurata Risso, 1810) & pelagic-neritic & Silva et al. (2013b) \\
\hline Atlantic cod (Gadus morhua L., 1758) & demersal; oceanodromous & Beamish (1980) \\
\hline Atlantic herring (Clupea harengus, L., 1758) & demersal; oceanodromous & Farmer (1980) \\
\hline Haddock (Melanogrammus aeglefinus L., 1758) & demersal; oceanodromous & Beamish (1980) \\
\hline Saithe (Pollachius virens L., 1758) & demersal; oceanodromous & Beamish (1980) \\
\hline Red hake (Urophycis chuss Walbaum, 1792) & demersal; oceanodromous & Farmer (1980) \\
\hline Atlantic mackerel (Scomber scombrus L., 1758) & pelagic-neritic; oceanodromous & Farmer (1980) \\
\hline Atlantic salmon (Salmo salar L., 1758) & demersal; anadromous & Beamish (1980); Silva et al. (2013b) \\
\hline Sea trout (Salmo trutta L., 1758) & pelagic-neritic; anadromous & Silva et al. (2013b) \\
\hline Brook trout (Salvelinus fontinalis Mitchill, 1814) & demersal; anadromous & Beamish (1980) \\
\hline Swordfish (Xiphias gladius L., 1758) & pelagic-oceanic; oceanodromous & Beamish (1980) \\
\hline Striped bass (Morone saxatilis Walbaum, 1792) & demersal; anadromous & Beamish (1980) \\
\hline Bluefish (Pomatomus saltatrix L., 1758) & pelagic-oceanic; oceanodromous & Beamish (1980) \\
\hline Squeteague (Cynoscion regalis Bloch and Schneider, 1801) & demersal; oceanodromous & Beamish (1980) \\
\hline \multicolumn{3}{|l|}{ Cetacea } \\
\hline Fin whales (Balaenoptera physalus L., 1758) & Pelagic-oceanic & Japha (1910) \\
\hline Sei whale (Balaenoptera borealis Lesson, 1828) & Pelagic-oceanic & Japha (1910) \\
\hline Harbour porpoise (Phocoena phocoena L., 1758) & Pelagic-oceanic & van Utrecht (1959) \\
\hline Western North Atlantic right whale, (Eubalaena glacialis Müller, 1776) & Pelagic-oceanic & Nichols and Hamilton (2004) \\
\hline Minke whale (Balaenoptera acutorostrata Lacépède, 1804) & Pelagic-oceanic & Nichols and Tscherter (2011) \\
\hline Killer whale (Orcinus orca L.) & Pelagic-oceanic & Samarra et al. (2012) \\
\hline
\end{tabular}

all individuals less than $39 \mathrm{~cm}$ long were taken in bottom trawls on the continental shelf or in coastal trap nets, whereas most animals more than $56 \mathrm{~cm}$ long were captured in mid-water trawls along the shelf edge or on the continental slope (Halliday 1991). According to Haedrich (1977), it is even quite possible that sea lamprey may often feed in deeper offshore waters as they have been caught at considerable depths: as deep as $4099 \mathrm{~m}$. It is interesting to note that sea lamprey and Pacific lamprey (Entosphenus tridentatus Gairdner in Richardson, 1836) seem to have in common the fact that they both prey upon demersal and pelagic hosts, and that they can be captured by trawls in benthic or pelagic environments.

A study by Orlov et al. (2008) aimed at better understanding the ecology of the parasitic life stage of the Pacific lamprey in the North Pacific is probably the most comprehensive study related to feeding ecology and spatial distribution of an anadromous lamprey species in the marine environment. By clustering the data on long-term bottom and mid-water trawlrecorded captures, Orlov et al. (2008) noticed that the average catches and frequency of occurrence of Pacific lamprey decreased with an increase in depth. In bottom trawl surveys, Pacific lamprey was found at a maximum depth of $1163 \mathrm{~m}$, and in mid-water trawls as deep as $1485 \mathrm{~m}$. The same study identified 10 preferred host species for the Pacific lamprey composed of demersal and pelagic groups of species such as flatfishes (4 species: Greenland halibut Reinhardtius hippoglossoides Walbaum, 1792; Pacific halibut Hippoglossus stenolepis Schmidt, 1904; Arrow-tooth flounder Atheresthes stomias Jordan and Gilbert, 1880; and Kamchatka flounder Atheresthes evermanni Jordan and Starks, 1904), salmon (3 species: Chum salmon Oncorhynchus keta Walbaum, 1792; sockeye salmon Oncorhynchus nerka Walbaum, 1792; and Chinook salmon Oncorhynchus tshawytscha Walbaum, 1792), codfish (2 species: Walleye Pollock Theragra chalcogramma Pallas, 1814; and Pacific cod Gadus macrocephalus Tilesius, 1810), and the Pacific herring (Clupea pallasii pallasii Valenciennes, 1847).

Skeletal muscle is an important fat reserve in the beginning of the sea lamprey spawning migration (Lança et al. 2011), representing in our study $21 \%-28 \%$ of the total muscle dry weight and $52 \%-79 \%$ of muscle total lipids. In fact, this is an empirical knowledge shared by professional fisherman and local consumers, who prefer lampreys caught in freshwater, in upstream reaches, after spending part of this fat reserve in their upstream migration. This fact was recently described for the River Minho's sea lampreys, for which there was a significant reduction in the amount of lipids in the muscle of those caught $65 \mathrm{~km}$ upstream from the sea in comparison with those caught at the river mouth (Araújo 2011). 
Triacylglycerols in fish are stored in various tissues, including muscle, liver, sub-dermal tissue and mesenteries and during starvation they are mobilized preferentially for basic maintenance and other metabolic needs (Adams 1999). The same occurs in lampreys, since they store large amounts of triacylglycerols in liver and body wall muscles (Plisetskaya 1980). The muscle fatty acid profile of the individuals from Groups I and II displays similarities, especially in terms of $M U F A$, which are the major fatty acids in neutral lipids, followed by $S F A$ and $P U F A$. These results are also in agreement with the common opinion that fish species accumulate depot lipids composed mainly of SFA and MUFA (Kozlova and Khotimchenko 2000, Pinela et al. 2009). The major SFA were C14:0 and

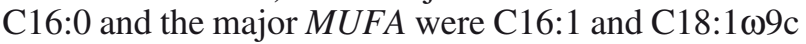
and sea lampreys showed a normal pattern for marine fish lipids, where EPA and DHA are dominant PUFA and $\omega 3 / \omega 6$ ratios showed a typical value that usually ranges from 4.7 to 14.4 (Henderson and Tocher 1987).

Our results revealed that 25 of the 31 fatty acids analysed contributed to the dissimilarity of muscle neutral lipid profile between Ggroups I and II, which raises the possibility of differences in sea lamprey preferential food sources and/or feeding strategies. The dissimilarity between the two groups was supported by five main differences related to the following fatty acids:

(i) Odd-chain fatty acids (C13:0, C17:0, C23:0). Several odd fatty acids are originally derived from bacteria and are considered useful markers of microbial presence on detritus (Lechevalier 1982, Mayzaud et al. 1989, Kaneda 1991, Rajendran et al. 1993, Napolitano 1999), especially the C15:0; C15iso; C15anteiso; C17:0; C17iso and C17anteiso fatty acids. What is very interesting to note is that individuals of Group II revealed the higher amounts for all three odd-chain fatty acids, which probably means that sea lampreys fed upon a dietary source rich in these fatty acids, like fish that include in their diet decaying matter or plant debris, namely the mugilidae (Almeida et al. 1993), or scavenger benthic species that feed on discards from commercial fishing vessels (Dunn et al. 2010).

(ii) Saturated fatty acids (C12:0, C14:0, C16:0, C18:0, C20:0 and C24:0) From these, we excluded short and medium chain fatty acids (i.e. C12:0, C14:0) and C16:0 and C18:0. The former are not useful markers in diet studies because they are almost oxidized before deposition in animal tissues, and when present in tissues they have arisen from de novo biosynthesis (Tocher 2003, Budge et al. 2006). C16:0 and C18:0 were eliminated because, although vertebrates synthesize few fatty acids, these tend to be restricted to C14:0, C16:0 and C18:0, which make them ubiquitous. Our attention was focused on C24:0. Long-chain saturated fatty acids (from C24:0 to C28:0) in the marine environment generally stem from higher plant waxes and are more abundant in deep than in surface sediments near the shore (Rielley et al. 1991, Muri et al.
2004). Group II is once again the group with the highest values of C24:0 (relative amount and frequency of occurrence), which raises the hypothesis that sea lampreys have a feeding strategy relatively close to the continent.

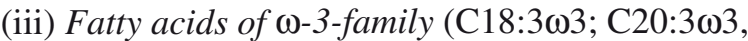
$\mathrm{C} 20: 5 \omega 3 ; \mathrm{C} 22: 5 \omega 3 ; \mathrm{C} 22: 6 \omega 3)$. C20:5 23 (diatoms) and C22:6 13 (dinoflagellates) are important phytoplankton markers (Napolitano 1999, Dalsgaard et al. 2003). In fact, algae are the only organisms that possess the enzymes for C20:5 133 and C22:6 133 production (Iverson 2009). Apart from the statistical differences, this result only reveals a typical scenario of a marine food web with a planktonic base for both groups.

(iv) Fatty acids of $\omega$-6-family (C18:2 $\omega 6, \mathrm{C} 18: 3 \omega 6$,

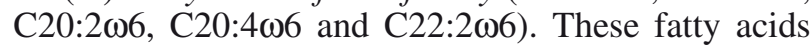
are possible markers of benthic algae (Sargent and Whittle 1981) and recognized markers of freshwater fish (Bell et al. 1986, Henderson and Tocher 1987, Käkelä, et al. 1993). Although present in both groups, the sea lampreys from Group II showed a tendency to have greater amounts of these fatty acids in their tissue, which indicates a diet with a more continental profile, i.e. fish species that belong to a food web with a strong input from estuarine environments;

(v) $C 24: 1 \omega 9$. This fatty acid is ubiquitous in the marine environment and is found at a few tenths of a percent in most marine organisms, including practically all marine fish. Only $18.6 \%$ of the animals from Group I had this fatty acid in their tissues, whereas it was present in all the animals from Group II in higher amounts that those found in Group I. Since this fatty acid was first described in elasmobranchs, it was first believed to be characteristic of fats of elasmobranch fish (original name: selacholeic acid) (Laposata 1998). However, based only on C24:1 199 , it is not possible to stress the importance of elasmobranchs in the feeding strategy of sea lampreys.

With respect to $\mathrm{C} 18: 1 \omega 9, \mathrm{C} 20: 1 \omega 9$ and $\mathrm{C} 22: 1 \omega 9$ fatty acids, our results also revealed significant differences. Generally when found in higher trophic level

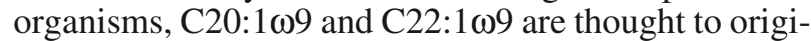
nate from copepods and they are also considered good trophic markers of zooplankton (herbivorous calanoid copepods) (Dalsgaard et al. 2003), whereas C18:169 is considered an important biomarker for carnivory. Investigations with marine fish showed that C20:1 19 is particularly abundant in many fish triacylglycerols and is derived from the corresponding C20:1 199 fatty alcohol in zooplanktonic wax esters (Ackman 1999). These results suggest that both feeding strategies may include hosts that have consumed copepods directly or consumed copepod consumers.

Host attachment and scarring data confirm that sea lamprey in the northwest Atlantic prey upon many species in at least three trophic levels (Table 5). Drevnick et al. (2006) corroborate this with a stable isotope analyses to assess the sea lamprey diet and confirm that anadromous sea lamprey do not feed at a single 
trophic level during the adult stage. According to these authors, the individuals sampled appeared to have fed on fish from both benthic and pelagic habitats.

In our opinion and based on our results, the sea lamprey clustered in Group II may have had a feeding strategy that promoted parasitism on demersal fish from the mesopelagic or even bathypelagic zone. This assumption is supported by two evidences. First, there are no catch data of lampreys attached to hosts (or free swimming), or records of scarred fish, in the bottom trawl fishery on the Portuguese continental shelf (unpublished data). Second, higher relative amounts of odd-chain fatty acids, especially C17:0, higher relative amounts of fatty acids of $\omega-6$ series, and the presence of the long-chain fatty acid C24:0 in $N L$ profile of sea lampreys from Group II, might indicate a feeding strategy that includes a diet with a more continental profile: fish species that have fed upon resources originating in estuarine environment.

In summary, based on our results, we have reasons to believe that it is possible to distinguish two feeding strategies in sea lampreys from the west coast of Portugal. Group I (i.e. Rivers Minho, Tagus, Vouga and ca. 39\% of the Lima) showed a feeding strategy that resembles a typical marine food web with a planktonic support. On the other hand, Group II (Douro, Mondego and ca. $61 \%$ of the Lima) showed a much more diverse feeding strategy, including the marine food web with a planktonic support described for Group I, together with biochemical clues that indicate that at least during part of their parasitic trophic phase these animals fed upon benthic opportunist carnivorous/scavenger fish species, probably elasmobranchs, and teleosts from a food web with a strong detritus and benthic algae signal. Regarding this last remark, we should be aware that in Portugal and Galicia it is common to observe sea lamprey juveniles feeding upon mugilids (Mugilidae) near the mouth of some estuaries between November and May (unpublished data; Silva et al. 2013b). This could explain the evidence of parasitic feeding on detritivorous species found in sea lampreys from Group II. The importance of this initial parasitic feeding stage becomes even more significant if we bear in mind that some of these animals stay no more than 14 months at sea. In a recent study, researchers from the University of Santiago de Compostela tagged and released sea lamprey juveniles that were already feeding upon mugilids. In the following year they recaptured one of the animals, which had increased its length from $21.8 \mathrm{~cm}$ to $89.5 \mathrm{~cm}$, and its mass from $20 \mathrm{~g}$ to $1218 \mathrm{~g}$ (Silva et al. 2013a).

The information concerning the feeding ecology of the parasitic stage of the sea lamprey may be particularly useful to support management actions aimed at conserving this threatened species. A hypothesis that we will try to test in the future is the possibility that these feeding strategies are associated with different dispersion tactics of this species during the parasitic stage. In fact, sea lamprey individuals that prefer- entially parasitize pelagic hosts can be engaged in a strategy that enhances dispersion but also increases the risk of not returning to continental waters to reproduce, versus a more conservative strategy with animals feeding mainly on demersal hosts with limited mobility and associated with the continental slope or even the ocean basin floor.

\section{ACKNOWLEDGEMENTS}

This study was financially supported by FEDER Funds through the Operational Programme for Competitiveness Factors - COMPETE and National Funds through the Foundation for Science and Technology (FCT) under the Strategic Project PEst-C/AGR/ UI0115/2011 and by the FCT through project PTDC/ BIA-BDE/71826/2006. We also thank our colleagues Catarina Mateus, Carlos Alexandre, Filipe Romão and Sílvia Pedro for helping with tissue sampling and preparation.

\section{REFERENCES}

Ackman R.G. 1999. Comparison of lipids in marine and freshwater organisms. In: Arts M.T., Wainman B.C. (eds), Lipids in Freshwater Ecosystems, Springer-Verlag, New York, pp. 263-298.

Ackman R.G. 2002. The gas chromatograph in practical analysis of common and uncommon fatty acids for the $21^{\text {st }}$ century. Anal. Chem. Acta 465: 175-192.

Adams S.M. 1999. Ecological role of lipids in the health and success of fish populations. In: Arts M.T., Wainman B.C. (eds), Lipids in Freshwater Ecosystems, Springer-Verlag, New York, pp. 123-160.

Almeida P.R., Moreira F., Costa J.L., Assis C.A., Costa M.J. 1993. The feeding strategies of Liza ramada (Risso, 1826) in fresh and brackish water in the River Tagus, Portugal. J. Fish Biol. 42: 95-109.

Anderson M.J., ter Braak C.J.F. 2003. Permutation tests for multifactorial analysis of variance. J. Stat. Comput. Simul. 73: 85-113.

Araújo M.J.F.S. 2011. Ecology and nutritional composition of the sea lamprey (Petromyzon marinus Linnaeus, 1758) in the River Minho's international stretch. MSc thesis. Institute of Biomedical Sciences Abel Salazar, University of Oporto, Oporto, 102 pp.

Beamish F.W.H. 1980. Biology of the North American anadromous sea lamprey. Can. J. Fish. Aquat. Sci. 37: 1924-1943.

Bell M.V., Henderson R.J., Sargent J.R. 1986. The role of polyunsaturated fatty acids in fish. Comp. Biochem. Physiol. 83B: 711-719.

Bird D.J., Potter I.C. 1983. Changes in the fatty acid composition of triacylglycerols and phospholipids during the life cycle of the lamprey Geotria australis Gray. Comp. Biochem. Physiol. 75 B: $31-41$

Bird D.J., Ellis D.J., Potter I.C. 1993. Comparisons between the fatty acid composition of the muscle and ovary of the nonparasitic lamprey Lampetra planeri (Bloch) and their counterparts in the anadromous and parasitic Lampetra fluviatilis (L.). Comp. Biochem. Physiol. 105B: 327-332.

Brett M.T., Muller-Navarra D.C., Persson J. 2009. Crustacean zooplankton fatty acid composition. In: M.T. Arts, M. Brett and M. Kainz, (eds), Lipids in Aquatic Ecosystems, Springer, New York, pp. 115-146.

Budge S.M., Iverson S.J., Koopman H.N. 2006. Studying trophic ecology in marine ecosystems using fatty acids: a primer on analysis and interpretation. Mar. Mammal Sci. 22: 759-801.

Cabral M.J., Almeida J., Almeida P.R., Dellinger T., Ferrand de Almeida N., Oliveira M.E., Palmeirim J.M., Queiroz A.I., Rogado L. , Santos-Reis M. (eds). 2005. Livro vermelho dos vertebrados de Portugal. Instituto de Conservação da Natureza, Lisbon, 660 pp. 
Clarke K.R. 1993. Non-parametric multivariate analysis of changes in community structure. Am. J. Ecol. 18: 117-143.

Dalsgaard J., St John M., Kattner G., Muller-Navarra D., Hagen W. 2003. Fatty acid trophic markers in the pelagic marine environment. Adv. Mar. Biol. 46: 225-340.

Doadrio I. 2001. Atlas y libro rojo de los peces continentales de España. Dirección General de Conservación de la Naturaleza, Museo Nacional de Ciencias Naturales, Madrid, 364 pp.

Drevnick P.E., Horgan M., Oris J., Kynard B.E. 2006. Ontogenic dynamics of mercury accumulation in Northwest Atlantic sea lamprey (Petromyzon marinus). Can. J. Fish. Aquat. Sci. 63: 1058-1066.

Dunn M.R., Szabo A., McVeagh M.S., Smith P.J. 2010. The diet of deepwater sharks and the benefits of using DNA identification of prey. Deep-Sea Res. Pt. I 57: 923-930.

Falk-Petersen S., Dahl T.M., Scott C.I., Sargent J.R., Gulliksen B., Kwasniewski S., Hop H., Millar R. 2002. Lipid biomarkers and trophic linkages between ctenophores and copepods in Svalbard waters. Mar. Ecol. Progr. Ser. 227: 187-194.

Farmer G.J. 1980. Biology and physiology of feeding in adult lampreys. Can. J. Fish. Aquat. Sci. 37: 1751-1760.

Freyhof J., Brooks E. 2011. European Red List of freshwater fishes. Publications Office of the European Union, Luxembourg, $61 \mathrm{pp}$

Freyhof J., Kottelat M. 2008. Petromyzon marinus. In: IUCN 2012. IUCN Red List of Threatened Species. Version 2012.2. <www. iucnredlist.org $>$ (accessed on 05 April 2013).

Gallant J., Harvey-Clark C., Myers R.A., Stokesbury M.J.W. 2006. Sea lamprey attached to a Greenland Shark in the St. Lawrence Estuary, Canada. NE. Naturalist 13: 35-38.

Haedrich R.C. 1977. A sea lamprey from the deep ocean. Copeia 4: 767-768.

Halliday R.C. 1991. Marine distribution of the sea lamprey (Petromyzon marinus) in the Northwest Atlantic. Can. J. Fish. Aquat. Sci. 48: 832-842.

Hendersen R.J., Sargent J.R. 1981. Lipid biosynthesis in rainbow trout Salmo gairdnerii, fed diets of differing lipid content. Comp. Biochem. Physiol. 69C: 31-37.

Henderson R.J., Tocher D.R. 1987. The lipid composition and biochemistry of freshwater fish. Prog. Lipid Res. 26: 281-347.

Iverson S.J. 2009. Tracing aquatic food webs using fatty acids: from qualitative indicators to quantitative determination. In: Arts M.T., Brett M., Kainz M. (eds), Lipids in Aquatic Ecosystems, Springer, New York, pp. 281-307.

IUCN France, MNHN, SFI, ONEMA 2010. La liste rouge des espèces menacées en France-poissons d'eau douce de France métropolitaine. IUCN, Paris. Available at www.uicn.fr/ IMG/ pdf/ Liste_rouge_France_Poissons d_eau_douce_de_metropole.pdf

Japha A. 1910. Weitere Beiträge zur Kenntnis der Walhaut. Zool. Jahrb. 12: 711-718

Jensen C., Schwartz F.J. 1994. Atlantic Ocean occurrences of the sea lamprey, Petromyzon marinus (Petromyzontiformes, Petromyzontidae), parasitizing sand-bar, Carcharhinus plumbeus, and dusky, C. obscurus (Carcharhiniformes: Carcharhinidae), sharks off North and South Carolina. Brimleyana 21: 69-72.

Jensen C., Schwartz F.J., Hopkins G. 1998. A sea lamprey (Petromyzon marinus)-tiger shark (Galeocerdo cuvier) parasitic relationship off North Carolina. J. Elisha Mitchell Scient. Soc. 114: 72-73.

Johns, R.B., Nichols P.D., Perry G.J. 1979. Fatty acid composition of ten marine algae from Australian waters. Phytochemistry 18: 799-802.

Kaiser K.L.E., Esterby S.R. 1991. Regression and cluster analysis of the acute toxicity of 207 chemicals to six species of biota and octanol/water partition coefficient. Sci. Total Environ. 109-110: 499-514.

Käkelä R., Hyvärinen H., Vainiotalo P. 1993. Fatty acid composition in liver and blubber of the Saimaa ringed seal (Phoca hispida saimensis) compared with that of the ringed seal (Phoca hispid botnica) and grey seal (Halichoerus grypus) from the Baltic. Comp. Biochem. Physiol. 105B: 553-565.

Kaneda T. 1991. Iso- and Anteiso-Fatty Acids in Bacteria: Biosynthesis, Function, and Taxonomic Significance. Microbiol. Rev. 55: 288-302.

Khotimchenko S.V., Vaskousky V.E. 1990. Distribution of C20 polyenoic fatty acids in red macrophytic algae. Bot. Mar. 33: 525-528.
Kozlova T.A., Khotimchenko S.V. 2000. Lipids and fatty acids of two pelagic cottoid fishes (Comephorus spp) endemic to Lake Baikal. Comp. Biochem. Physiol. 126B: 477-485.

Lança M.J., Rosado C., Machado M., Ferreira R., Alves-Pereira I., Quintella B.R., Almeida P.R. 2011. Can muscle fatty acid signature be used to distinguish diets during the marine trophic phase of sea lamprey (Petromyzon marinus, L.)? Comp. Biochem. Physiol. 159B: 26-39.

Laposata M. 1998. Fatty acid ethyl esters: ethanol metabolites with mediate ethanol-induced organ damage and serve as markers of ethanol intake. Prog. Lipid Res. 37: 307-316.

Larsen L.O. 1980. Physiology of adult lampreys, with special regard to natural starvation, reproduction, and death after spawning. Can. J. Fish. Aquat. Sci. 37: 1762-1777.

Lechevalier M.P. 1982. Lipids in bacterial taxonomy. In: Laskin A.I., Lechevalier H.A. (eds), CRC Handbook of Microbiology, CRC Press, Inc. Boca Raton, Florida, pp. 435-541.

Leger C., Fremont L., Boudon M. 1981. Fatty acid composition of the lipids in the trout - I. Influence of dietary fatty acids on the triglyceride fatty acid desaturation in serum, adipose tissue, liver, white and red muscle. Comp. Biochem. Physiol. 69 B: 99-105.

Mansueti J. 1962. Distribution of small, newly metamorphosed sea lampreys, Petromyzon marinus, and their parasitism on menhaden, Brevoortia tyrannus, in mid-Chesapeake Bay during winter months. Chesapeake Sci. 3: 137-139.

Mateus C.S., Rodríguez-Muñoz R., Quintella B.R., Alves M.J., Almeida P.R. 2012. Lampreys of the Iberian Peninsula: distribution, population status and conservation. Endang. Spec. Res. 16: $183-198$.

Mayzaud P., Chanut J.P., Ackman R.G. 1989. Seasonal changes of the biochemical composition of marine particulate matter with special reference to fatty acids and sterols. Mar. Ecol. Prog. Ser. 56: 189-204.

Morrison W.R., Smith L.M. 1964. Preparation of fatty acid methyl esters and dimethylacetals from lipids with boron fluoridemethanol. J. Lipid Res. 5: 600-608.

Muri G., Wakeham S.G., PeaseT.K., Fanganeli J. 2004. Evaluation of lipid biomarkers as indicators of changes in organic matter delivery to sediments from Lake Planina, a remote mountain lake in NW Slovenia. Org. Geochem. 35: 1083-1093.

Napolitano G.E. 1999. Fatty acids as trophic and chemical markers in freshwater ecosystems. In: Arts M.T., Wainman B.C. (eds), Lipids in Freshwater Ecosystems, Springer-Verlag, New York, pp. 21-44

Nichols O.C., Hamilton P.K. 2004. Occurrence of the parasitic sea lamprey, Petromyzon marinus, on western North Atlantic right whales, Eubalaena glacialis. Environ. Biol. Fishes 71: 413-417.

Nichols O.C., Tscherter U.T. 2011. Feeding of sea lampreys Petromyzon marinus on minke whales Balaenoptera acutorostrata in the St Lawrence Estuary, Canada. J. Fish Biol. 78: 338-343.

Orlov A.M., Savinykh V.F., Pelenev D.V. 2008. Features of spatial distribution and size composition of Pacific lamprey Lampetra tridentata in the North Pacific. Russ. J. Mar. Biol. 34: 276-287.

Parrish C.C., Abrajano T.A., Budge S.M., Helleur R.J., Hudson E.D., Pulchan K., Ramos C. 2000. Lipid and phenolic biomarkers in marine ecosystems: analysis and applications. In: Wangersky P. (ed.), The Handbook of Environmental Chemistry Part D, Marine Chemistry, Springer-Verlag, Berlin Heidelberg, pp. 193-223.

Pinela S., Quintella B.R., Almeida P.R., Lança M.J. 2009. Comparison of the fatty acid profile of muscle neutral lipids and phospholipids of up-river anadromous sea lamprey (Petromyzon marinus L.) from three Portuguese river basins. Sci. Mar. 73: $785-795$

Plisetskaya E. 1980. Fatty acid levels in blood of cyclostomes and fish. Environ. Biol. Fish 5: 273-290.

Potter I.C. 1980. Ecology of larval and metamorphosing lampreys. Can. J. Fish. Aquat. Sci. 37: 1641-1656.

Rajendran N., SuwaY., Urushigawa Y. 1993. Distribution of phospholipid ester-linked fatty acids biomarkers for bacteria in the sediment of Ise Bay. Mar. Chem. 42: 39-56.

Renaud C.B., Gill H.S., Potter I.C. 2009. Relationships between the diets and characteristics of the dentition, buccal glands and velar tentacles of the adults of the parasitic species of lamprey. J. Zool. 278: 231-242.

Rielley G., Collier R.J., Jones D.M., Egliton G. 1991. The biogeo- 
chemistry of Ellesmene Lake, UK - I: source correlation of leaf wax inputs to the sedimentary lipid record. Org. Geochem. 17: 901-912.

Samarra F.I.P., Fennell A., Aoki K., Deecke V.B., Miller P.J.O. 2012. Persistence of skin marks on killer whales (Orcinus orca) caused by the parasitic sea lamprey (Petromyzon marinus) in Iceland. Mar. Mammal Sci. 28: 395-401.

Sargent J.R., Whittle K.J. 1981. Lipids and hydrocarbons in the marine food web. In: Longhurst A.R. (ed.), Analysis of Marine Ecosystems, Academic Press, London, pp. 491-533.

Sargent J.R., Parkes R.J. Muller-Harvey L., Henderson R.J. 1987. Lipid biomarkers in marine ecology. In: Sleigh M.A. (ed.), Microbes in the Sea, Wiley and Sons, New York, pp. 119-138.

Sheridan M.A. 1988. Lipid dynamics in fish: aspects of absorption, transportation, deposition and mobilization. Comp. Biochem. Physiol. 90B: 679-690.

Silva S., Servia M.J., Vieira-Lanero R., Barca S., Cobo F. 2013a Life cycle of the sea lamprey Petromyzon marinus: duration of and growth in the marine life stage. Aquat. Biol. 18: 59-62.

Silva S., Servia M.J., Vieira-Lanero R., Cobo F. 2013b. Down- stream migration and hematophagous feeding of newly metamorphosed sea lampreys (Petromyzon marinus Linnaeus, 1758). Hydrobiologia 700: 277-286.

Tocher R.D. 2003. Metabolism and functions of lipids and fatty acids in teleost fish. Rev. Fish. Sci. 11: 107-184.

van Utrecht W.L. 1959. Wounds and scars in the skin of the common porpoise Phocaena phocaena (L.). Mammalia 13: 100-122.

Wannigama G.P., Volkman J.K., Gillan F.T., Nichols P.D., Johns R.B. 1981. A comparison of lipid components of the fresh and dead leaves and pneumatophores of the mangrove Avicennia marina. Phytochemistry 20: 659-666.

Warwick R.M., Platt H.M. Clarke K.R., Agard J., Gobin J. 1990. Analysis of macrobenthic and microbenthic community structure in relationship to pollution and disturbance in Hamilton Harbour, Bermuda. J. Exp. Biol. Ecol. 138: 119-142.

Scient. ed.: A. Sabatés.

Received November 11, 2012. Accepted April 15, 2013.

Published online May 28, 2013. 